\title{
THE SECRET OF PRESERVED QUALITY OF LIFE IN ELDERLY PATIENTS WITH PERIPHERAL ARTERY DISEASE AND DECREASED ANKLE-BRACHIAL INDEX
}

\author{
Anna-Boróka Tusa ${ }^{1}$, Annamária Magdás ${ }^{1,2}$, Réka-Júlia Tusa², Al. Incze ${ }^{3}$ \\ ${ }^{1}$ Spitalul Clinic Județean de Urgență Mureș \\ ${ }^{2}$ Universitatea de Medicină și Farmacie Tîrgu Mureș \\ ${ }^{3}$ Centrul Medical Sfântu Gheorghe, Tîrgu Mureș \\ Autor corespondent: Șef de lucrări, Dr. Magdás Annamária \\ e-mail: annamaria.magdas@umftgm.ro
}

\section{Summary}

Objective. In lower limb peripheral artery disease the most commonly used method for the assessment of the main arterial system is represented by the determination of ankle-brachial index $(A B I)$. The post-occlusive reactive hyperaemia (PORH) is a controversial method used for the evaluation of primary collateral circulation. The follow-up of these patients has an underestimated part, their quality of life. The aim of this study is to evaluate this and highlight the importance of the PORH in the sight of optimal treatment.

Method. 34 patients diagnosed with lower extremity artery disease, receiving conservative treatment, the ankle-brachial index was defined with a Doppler Bistos BT-200, $8 \mathrm{MHz}$ device, the PORH was evaluated with a Bidop ES-100V, an instrument which sends information for a Smart-V-Link software. To assess the quality of life we used the VascuQol-6 test.

Results. The age (mean $\pm S D$ ) of the patients was $67.24 \pm 9.51,52.92 \%$ were active smokers. A significant positive correlation was found between PORH and the results of VascuQol-6 test $(p=0.02, r=0.38)$ and an inverse correlation between $A B I<0.5$ and VascuQol-6 $>12$. We noticed a significant difference between the VascuQol-6 result at smokers and non-smokers $(p=0.02)$.

Conclusions. The quality of life can be acceptable at patients with significant stenosis on the main artery and decreased ankle-brachial index due to presence of the collateral artery system with a maintained ability of vasodilatation represented by PORH. The efficiency of the treatmet is based on quitting smoking, starting programs which are helping patients to quit smoking would be useful.

Keywords: elderly, peripheral artery disease, quality of life, reactive hyperaemia, anklebrachial index

\section{Rezumat}

Obiectiv. Pentru aprecierea stării patului vascular arterial în arteriopatie cronică obliterantă a membrelor inferioare (ACOMI), pe lângă indicele gleznă-braț (IGB), hiperemia reactivă postocluzivă (PORH) reprezintă un subiect controversat. Pe lângă evaluarea rezervei 


\section{INTER}

vasodilatatoare a patului vascular distal, calitatea vieții pacientului este subevaluată. Scopul studiului nostru constă în evaluarea calității vieții la pacienții cu ACOMI, respectiv accentuarea importanței hiperemiei reactive postocluzive în vederea tratamentului optimal.

Metodă. Am desfășurat un studiu prospectiv care include 34 de pacienți cu ACOMI, sub tratament conservator. IGB a fost identificat cu ajutorul unui aparat Doppler Bistos BT-200, $8 \mathrm{MHz}$. Hiperemia reactivă postocluzivă a fost evaluată cu un instrument Bidop ES-100V, informațiile au fost transmise pentru un software Smart-V-Link. Pentru a aprecia calitatea vieții pacienților am utilizat testul VascuQol-6.

Rezultate. Vârsta medie a fost $67,24 \pm 9,51$ ani, 52,92\% dintre pacienți au fost fumători activi. $S$-a evidențiat corelație pozitivă semnificativă între PORH și punctajele chestionarului VascuQol-6 $(p=0 ., 02, r=0,38)$, corelație inversă între IGB $<0,5$ și VascuQol-6 $>12$ puncte. Comparând punctajele obținute prin VascuQol-6 în rândul fumătorilor și nefumătorilor, am observat o diferență semnificativă statistic $(p=0,02)$.

Concluzii. La pacienții cu stenoze semnificative ale axului arterial principal, cu IGB scăzut, calitatea vieții poate fi acceptabilă. Acest fapt se poate datora prezenței sistemului arterial colateral cu capacitate vasodilatatoare păstrată, reprezentată prin PORH crescut. Abandonarea fumatului trebuie să fie baza oricărui tratament, însă asta reprezintă un obstacol de multe ori inevitabil. Realizarea unui program pentru a sprijini pacienții în abandonarea fumatului ar fi util.

Cuvinte cheie: vârstnici, arteriopatie, calitatea vieții, hiperemie reactivă, indice gleznă-braț. 


\section{Introduction}

The burden of peripheral artery disease is increasing with age and is affecting patients quality of life. The first-line, low-cost and useful tool recommended by the guidelines to idenitify lower extremity artery disease (LEAD) is the ankle-brachial index (ABI). The $A B I$ is the first diagnostic step after clinical examination. An $A B I \leq 0.90$ has $75 \%$ sensitivity and $86 \%$ specificity to diagnose LEAD. Patients with borderline $A B I$ (0.90-1.00) need further diagnostic tests ${ }^{(1)}$. Although, the $A B I$ is decreased, elderly patients could still have an acceptable quality of life (QoL) perhaps due to the preformed collateral arterioles. Currently, we have only invasive imaging methods to identify these collateral circulation. The role of the non-invasive post-occlusive reactive hyperaemia (PORH) in order to identify the collateral reserve is still controversial. Therefore, the aim of this study was to assess QoL of elderly patients suffering from LEAD and to highlight the clinical importance of PORH.

\section{Methods}

A number of 34 subjects were included in our study (26 male, 8 female) diagnosed with lower extremity artery disease, the mean age was $67.24 \pm 9.5$. The study was conducted in accordance with the World Medical Association's Declaration of Helsinki. Patients younger than 50 year with iliofemoral or femuro-popliteal bypass, gangrene and amputation were excluded from the study. Demographic data, associated diseases, cardiovascular risk factors, drug therapy were collected in a questionnaire. Ankle-brachial index was determined with a $8 \mathrm{MHz}$ handheld Doppler
Bistos BT-200 device. The post occlusive reactive hyperemia (PORH) measurements were performed with Bidop ES-100V 3 device which transmited the information to the Smart-V-Link ${ }^{\circledR}$ software. During examination the individulas were in supine position, the sensor of the Bidop ES device was fixed on the plantar surface of the hallux. A pneumatic cuff was placed on the calf. After identification of baseline peripheral perfusion (PP) we provoked ischaemia for 3 minutes. After cuff deflation at maximum speed, post-occlusive flow was measured for further 4 minutes (1 measurement/60 $\mathrm{sec})$.We evaluated the quality of life of our patients with the help of the VascuQol-6 test wich represents a simplified version of VascuQol-25 and it is a valid and responsive instrument for the assessment of healthrelated quality of life in peripheral artery disease (PAD). The short version, VascuQoL6 , was developed based on the psychometric properties of VascuQol-25 in Sweden. This shortened item evaluates the physical abilities, social activities, emotional wellbeing of our patients ${ }^{(2)}$. Statistical analysis was performed with GraphPad Prism 6 program and the correlations were studied using Pearson's correlation test. The level of statistical significance was set at $95 \%$ with $\alpha \leq 0.05$.

\section{Results}

We observed the smoking habits of our patients, according to this $4(11.76 \%)$ of them were non-smokers, 12 (35.29\%) were former smokers and 18 (52.92\%) active smokers, among this, $30(88.23 \%)$ of them were diagnosed with arterial hypertension. All of our patients completed the VascuQol-6 test (max. 24 points) their mean result was $14 \pm 4.16$ points with an 8 point minimum and 


\section{INTER}

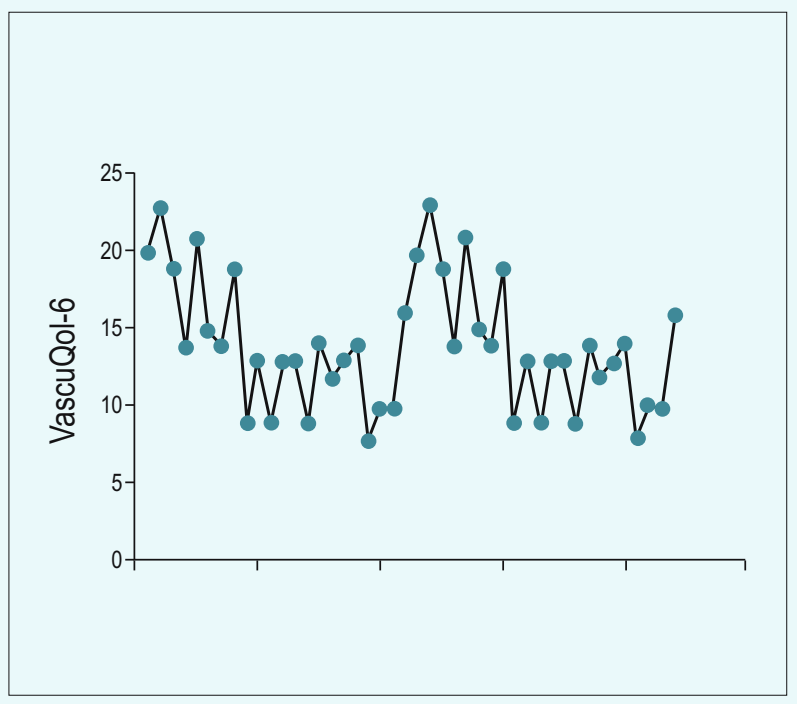

Figure 1. VascQol-6 test results

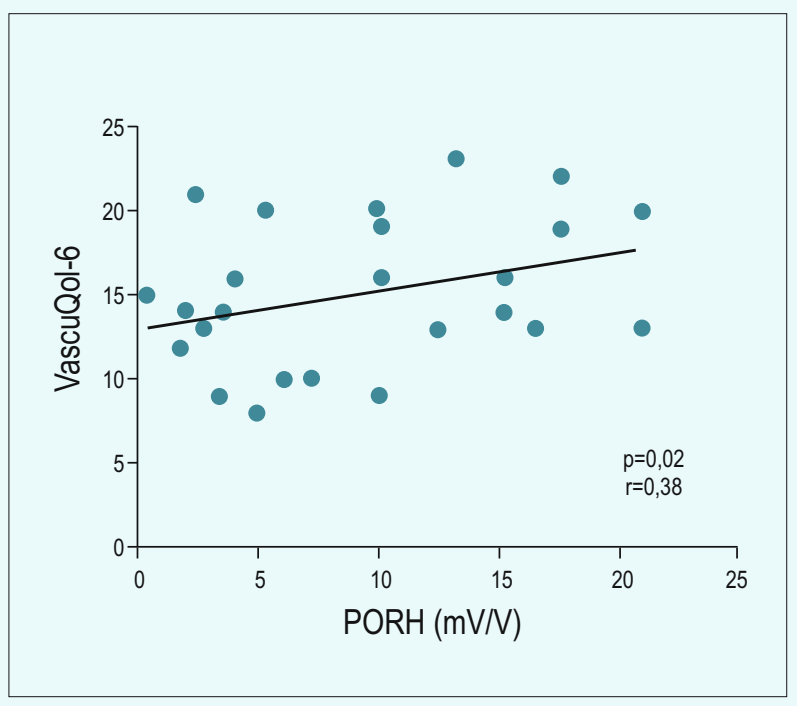

Figure 3. Pearson's correlation between VascuQol-6 and $\mathrm{PORH}$

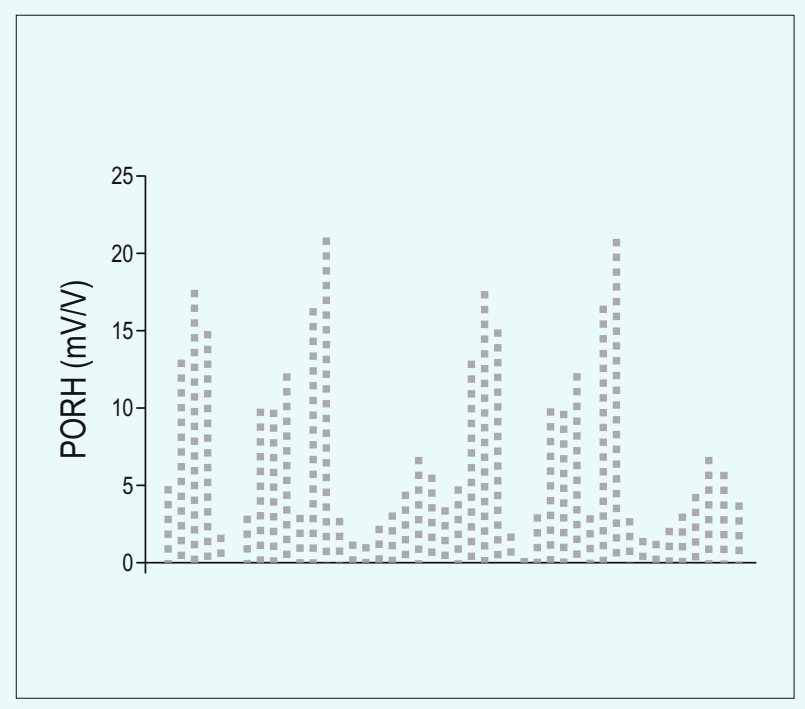

Figure 2. Post-occlusive reactiv hyperaemia test results

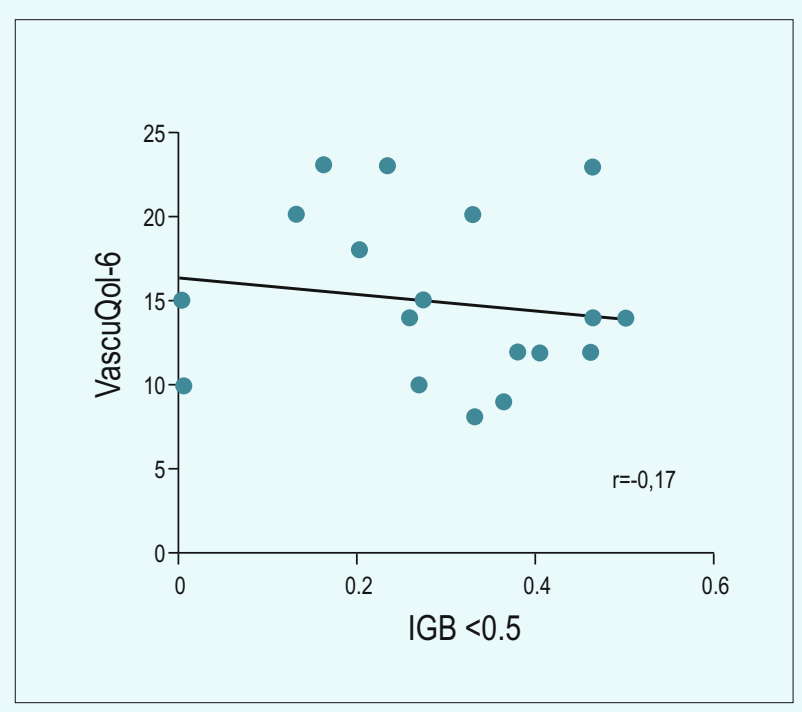

Figure 4. Pearson's correlation between VascuQol-6 $>12$ and $A B I<0.5$ 


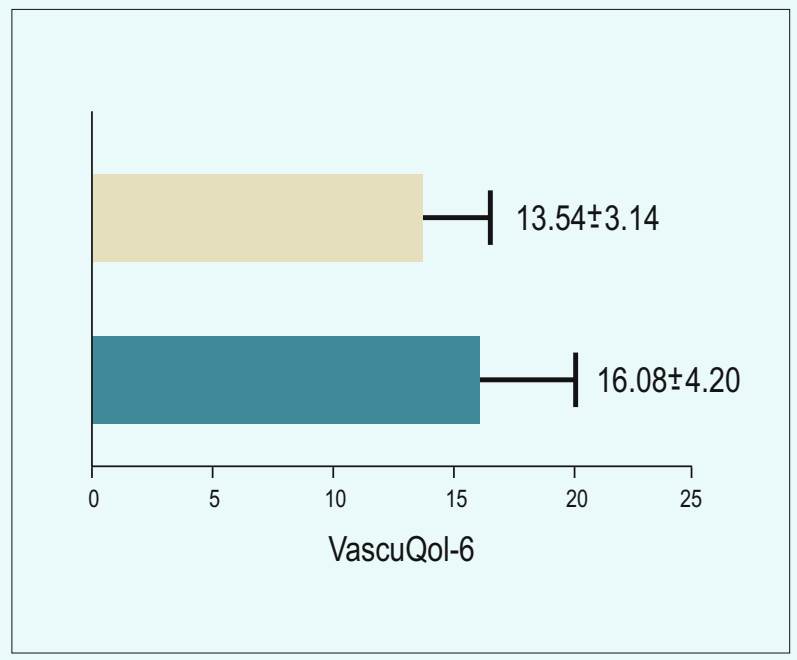

Figure 5. VascuQol-6 results, smokers versus nonsmokers

23 point maximum (figure 1 ). The $\mathrm{PORH}$ values varies between $0.8 \mathrm{mV} / \mathrm{V}$ and 21 $\mathrm{mV} / \mathrm{V}$, showing a mean value of $8.23 \pm 4.56$ $\mathrm{mV} / \mathrm{V}$ of peripheral perfusion (figure 2 ).

The values of the post-occlusive reactive hyperaemia are positively correlated to VascuQol-6 test points $(p=0.02, r=0.38)$ (figure 3 ). After we compared the $A B I$ values (mean $0.48 \pm 0.22$ ) $<0.5$ and the VascuQol-6 $>12$ points, we found a negative correlation $(r=-0.17)$ (figure 4). The VascuQol-6 results in the group of smokers versus nonsmokers and former smokers was $13.54 \pm 3.14$ versus $16.08 \pm 4.20(p=0.02)$ (figure 5$)$.

\section{Discussion}

In our study we evaluated the quality of life of our patients diagnosed with lower extremity peripheral artery disease and the importance of PORH in the assessment of primary collateral circulation. We found that the results of the VascuQol-6 test are $58.33 \%$ (14 points) in general, wich is an acceptable percent at pacients with a mean $\mathrm{ABI}$ of 0.48 . The results of $\mathrm{PORH}$ are showing a mean value above $8 \mathrm{mV} / \mathrm{V}$, this can reflect the presence of the primary collateral circulation at the level of the affected lower limb ${ }^{(3)}$.

After comparing these two results, the VascuQol-6 and PORH we found a significant and positive correlation, which means that the quality of life of these patients depends of the peripheral perfusion of the lower limbs.After this, VascuQol-6 results above 12 points were compared with $A B I$ values under 0.5 , as result we get an inverse correlation without statistical significance. Therefore, the symptomatology of these individuals is more correlated to the results of the PORH than the values of $A B I$. Despite the decreased values of $A B I$ the VascuQol-6 score is more than acceptable.

An important fact about PAD patients is the presence of smoking, as we know smoking is a potential risk factor for symptomatic PAD. Many health effects of smoking are reversible, but the risk for developing PAD seems to persist $^{(4)}$.

After comparing the smokers versus nonsmokers and former smokers quality of life results, the non-smokers quality of life was significantly better, they achieved higher score. Cigarette smoking may confer a detrimental effect on calf muscle tissue oxygenation in patients who smoke as compared to patients who are non-smokers. Calf muscle blood flow has been found to be reduced in smokers ${ }^{(5)}$.

The method of the post-occlusive reactiv hyperaemia seems to be a proper and lowcost way to assess the blood volume changes in the primary collateral circulation next to the $A B I$. This can help in therapeutic decision making in order to triage the patients who needs further high-cost investigations. After taking advantage of all non-invasive investigation methods ( $\mathrm{PORH}, \mathrm{ABI}$, Duplex Doppler) we can take the patient to the level of performant imaging methods (angio-CT, $\mathrm{MRI}$ ) and surgical approach. 


\section{INTERNAL}

\section{Original papers}

\section{Conclusions}

There are elderly PAD patients, with decreased ankle-brachial index and preserved quality of life, in these cases the acceptable quality of life is provided by the collateral circulation but there is no consensus available regarding the assessment method for this. The method of $\mathrm{PORH}$ seems to reflect the peripheral perfusion and the vasodilatating capacity of these arteries. In our experience there are elderly patients without episode of critical ischemia during the evolution of this pathology and decades of unchanged symptomatology thanks to the progressive development of the primary collateral circulation, this is contrary to other published findings which are claiming that among older adults int he community those with $A B I<1.0$ were independently associated with reduced QoL status ${ }^{(6)}$.

The long term follow-up of these patients includes choosing the best therapy, informing the patients about the importance of exercise therapy and smoking cessation.

\section{References}

1. 2017 ESC Guidelines on the Diagnosis and Treatment of Peripheral Arterial Diseases, in collaboration with the European Society for Vascular Surgery (ESVS).

2. Nordanstig J, Wann-Hansson C, Karlsson J et al., Vascular Quality of Life Questionnaire-6 facilitates health-related quality of life assessment in peripheral arterial disease, J Vasc. Surg., 2014 Mar, 59(3):700-7.

3. Cosmin Carasca, Annamaria Magdas, Al. Incze, Assessment of Post-Occlusive Reactive Hyperaemia in the Evaluation of Endothelial Function in Patients with Lower Extremity Artery Disease, Acta Medica Marisiensis, 2017 Sept, 63(3):129-132

4. Edith M.Willigendael MD, Joep A.W.Teijink MD, PhD, Marie-LouiseBartelink MD, PhD et al., Influence of smoking on incidence and prevalence of peripheral arterial disease, J Vasc Surg., 2004 Dec; 40(6):1158-65.

5. Cynthia Fritschi, PhD, Eileen G. Collins, PhD, Susan O'Connell, MHA, et al., Effects of Smoking Status on Walking Ability and Health-related Quality-of-Life in Patients with Peripheral Arterial Disease, J Cardiovasc Nurs. 2013 Jul-Aug; 28(4): 380386.

6. Aozhou Wu, Josef Coresh, Elizabeth Selvin, et al., Lower Extremity Peripheral Artery Disease and Quality of Life Among Older Individuals in the Community, Journal of the American Heart Association, 2017 Jan., $6 e 004519$. 